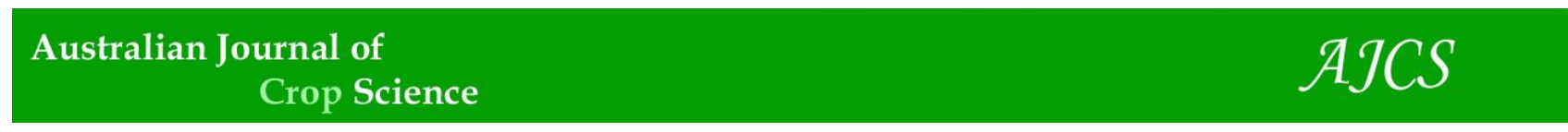

AJCS 12(06):985-989 (2018)

ISSN:1835-2707

doi: 10.21475/ajcs.18.12.06.PNE1087

\title{
Ryegrass (Lolium multiflorum Lam.) seed germination and vigor under saline stress
}

\author{
Aline Klug Radke*, Paulo Eduardo Rocha Eberhardt, Andrea Bicca noguez Martins, Fernanda da Motta \\ Xavier, Vanessa Pinto Gonçalves, Michele Renata Revers Meneguzzo, Carlos Eduardo da Silva Pedroso, \\ Francisco Amaral Villela
}

\author{
Departamento de Fitotecnia, Programa de Pós- Graduação em Ciência e Tecnologia de Sementes, Faculdade de \\ Agronomia Eliseu Maciel, Universidade Federal de Pelotas. FAEM/UFPel, Caixa postal 354, 96010-900 - Pelotas, RS, \\ Brasil
}

\section{*Corresponding author: alinekradke@hotmail.com}

\begin{abstract}
Ryegrass (Lolium multiflorum Lam.) is forage with the potential to increase pasture area in Southern Brazil. It is an option for more profitable and intensive use of floodplain areas during the cold seasons of the year. However, irrigation of crops in these areas in the summer can result in the salinization of the soils that have inadequate drainage, preventing the removal of salt by leaching. The objective of this study was to evaluate the performance of ryegrass seeds using different concentrations of sodium chloride. Four commercial ryegrass cultivars of PGG Wrightson Seeds Brazil were used: Inia Bakarat, Inia Scorpio, Inia Camaro, and La Estanzuela 284. Saline substrates consisted of Germitest ${ }^{\boxplus}$ paper wetted with sodium chloride solution at five osmotic potentials $(0,-0.2,-0.4,-$ 0.6 and $-0.8 \mathrm{MPa}$ ). The study was conducted at the "Flavio Rocha" Didactic Seeds Analysis Laboratory and involved analysis of the following indicators of salt stress response: germination (\%), first germination count (\%), plantlet length (cm), and plantlet dry phytomass ( $\mathrm{mg} / \mathrm{seedling}$ ). The results showed that saline stress conditions caused by reduced osmotic potential affected ryegrass seed germination and vigor, as well as decreased the stature of the aerial and root parts of the seedlings. Out of the cultivars evaluated, La Estanzuela 284 was the most tolerant to saline stress. It is possible to cultivate ryegrass in areas with salinity up to mean values of $-0.2 \mathrm{MPa}$ osmotic potential. In this study, no significant decrease in seedling performance was observed.
\end{abstract}

Keywords: Lolium multiflorum Lam., osmotic potentials, substrate salinity.

Abbreviations: MPa_mega pascal.

\section{Introduction}

In the South region of Rio Grande do Sul in Brazil, the water used for crop irrigation is derived from the Laguna dos Patos, a lagoon which is linked to the Atlantic Ocean. In periods of low rainfall, the area suffers from the entry of saline water, resulting in an increase in soil salinity (Carmona, 2011).

Saline soils occur in flat areas of the Coastal Plain region of the Laguna dos Patos (Bissani et al., 2008) and in regions where irrigated rice is cultivated. In these areas, soil salinization can occur over time, with inadequate drainage impeding salt removal through leaching.

For more profitable and intensive use of the floodplain areas during the cold seasons of the year, one alternative would be to introduce cultivated pastures, an option which addresses the lack of natural pasture for animals during this period (Klafke et al., 2012). In this context, ryegrass (Lolium multiflorum Lam.) is highly demanded forage for increasing the area of cultivated pasture in the South region of Brazil (Terra-Lopes et al., 2009).

Studying of salinity tolerance in plants is particularly important since salt constitutes a limiting factor for agricultural production (Harter et al., 2014). Salinity can alter both the physiological and chemical functions of plants, causing osmotic stress, which results disturbances in hydric of plants relationships, alterations in the absorption and use of essential nutrients, and the accumulation of toxic ions (Amorin et al., 2010). Seeds are significantly influenced by soil salinity conditions. For seeds with teguments that can be permeated by salt, the presence of salinity can cause a loss in germinability (Adreo-Souza et al., 2010). A high salt content, especially sodium chloride $(\mathrm{NaCl})$, can inhibit germination due to reduced osmotic potential, causing losses in other stages of the process (Lima et al., 2005).

Plant growth processes are particularly sensitive to the effect of the salt. Echer et al. (2010) demonstrated that a decrease in turgidity may cause a decrease in growth rate. Thus, small decreases in available water content and turgescence may slow down plant growth or even prevent it altogether. In this sense, initial growth rate and biomass production may aid in assessing the degree of stress and the ability of the plant to overcome saline stress (Morais et al., 2011).

One of the most widespread methods for determining plant tolerance to excess salt is by observing the germination percentage in saline substrates (Lima and Torres, 2009). In view of the high forage potential of the ryegrass species and the lack of information regarding the 
behavior of its seeds in saline environments, the aim of this study was to evaluate the seed performance of ryegrass cultivars using different $\mathrm{NaCl}$ concentrations.

\section{Results and discussion}

\section{Physiological quality}

All of the cultivars presented quadratic germination responses with increased salinity levels. The result was practically the same for all of the cultivars. However, Inia Camaro and La Estanzuela 284 cultivars differed from the rest by presenting higher maximum germination percentages and in higher salinity levels (Fig. 1A). The most negative values of the $1^{\text {st }}$ and $2^{\text {nd }}$ degree coefficients determined both the highest maximum points and the lowest declivities with increased levels of salt, so that even with the highest salinity levels tested, germination percentages close to $40 \%$ were still observed. The Bakara cultivar presented an intermediate response in terms of germination. This cultivar presented a high $2^{\text {nd }}$ degree coefficient; however, the declivity was intense immediately after the maximum point $(-0.2)$ and especially after -0.4 . The Escorpio cultivar showed the most sensitivity to increased salinity. The highest germination value was the intercept itself; and thus, it was already sensitive to the lowest salinity levels tested. This cultivar presented the lowest $2^{\text {nd }}$ degree angular coefficient, with the declivity practically determining the fall in germination with increased salinity until percentages were close to zero. Similarly, at the highest salinity level, the Bakara cultivar was shown to be quite sensitive and also presented insignificant responses to the germination. A decrease in the germination percentage with decreasing osmotic potentials was also reported by other researchers, both with perennial ryegrass (Nizam, 2011) and annual ryegrass (Klafke et al. 2012).

Similarly, Torres (2007) observed that the detrimental effect of excess salt caused a significant reduction in germination of watermelon (Citrullus lanatus Schrad.) seeds. When the results of the first count were compared with those of the final germination percentage, the first count data were the most affected by increased saline concentrations in the treatments. This is expected because speed of germination is the first parameter to be affected by reduced water availability.

All of the cultivars presented linear responses in the first germination count with increased salinity levels (Fig. 1B). The greatest tolerance was reported for the Estanzuela cultivar, at the 0.2 and -0.4 levels, determining a model with a higher intercept compared to the other cultivars. In connection with this aspect, the lower response declivity of this cultivar compared to the Bakara and Escorpio cultivars differentiates the Estanzuela cultivar with regard to seed vigor in more saline media. The Camaro cultivar presented a similar intercept to the others (except Estanzuela), but a lower declivity coefficient with increased salinity levels. Therefore, Estanzuela and Camaro cultivars presented the highest saline stress tolerance linear models, demonstrated especially by the positive first germination count (germination percentage close to $20 \%$ ), even at the highest tested saline level. The Bakara and Escorpio cultivars presented very similar responses for the first germination count due to increased saline levels. Both equations showed higher declivities due to lack of germination in the first count, when subjected to higher saline levels.

In general, decreases in osmotic potential of $0.1 \mathrm{Mpa}$ resulted in a 9.8 to 14 percentage point reduction in first count germination, depending on the cultivar.

According to Amorin et al. (2010), an excess of salt can disturb physiological and biochemical functions in plants, altering the absorption and use of essential nutrients, as well as resulting in the accumulation of toxic ions. As a result of this disturbance, a reduction occurs in the absorption of other mineral nutrients, especially $\mathrm{NO}_{3}^{-}, \mathrm{K}^{+}$, and $\mathrm{Ca}^{2+}$ (Larcher, 2000).

\section{Initial development}

The length of the aerial part of the plant was very similar among the cultivars and showed a quadratic response to the different saline levels (Fig. 2A). The cultivars presented high tolerances to the lowest levels of salt. So, the maximum point was verified at approximately the lowest level tested ($0.2)$, and at the second level $(-0.4)$ the values were very similar to those verified at the intercepts without the effect of the treatments. From the second level onwards, the models (for all the cultivars) showed increased declivity response, which resulted in reductions of approximately $60 \%$ in the length of the aerial part of the plants subjected to the highest saline levels.

These results suggest that the salt used to decrease the osmotic potential caused toxic effects in the ryegrass after seed germination, causing severe damage to plantlet growth. In cowpea seeds, Deuner et al. (2011) also observed a constant ratio reduction in the length of the aerial and root part variables, caused by the decreased osmotic potential at the highest salt concentrations tested.

As described by Munns and Tester (2008), salinity can affect various physiological processes, including photosynthesis, reducing the production and allocation of biomass. This occurs because saline stress, specifically associated with $\mathrm{NaCl}$ accumulation in the tissues, causes a reduction in the ATP synthesis processes connected to the photochemical phase of photosynthesis, as well as promoting alterations in the respiratory process, nitrogen assimilation, and metabolism of proteins.

Root length presented the greatest difference between cultivars when these were subjected to salinity (Fig. 2B). The responses were similar under the effect of salinity. The root length for all of the cultivars was affected by increased saline concentrations, with reductions of approximately $75 \%$ for the highest saline concentrations. However, there were subtle differences between the models for the different cultivars. The root length of the Bakara cultivar presented a higher intercept value, but greater sensitivity to increased saline concentrations. The Camaro and Escorpio cultivars were the least affected up to the second saline level tested $(-0.4)$. From this concentration onwards, the Camaro cultivar presented greater declivity in relation to the Escorpio cultivar. On the other hand, the Estanzuela cultivar has a higher intercept than the Escorpio cultivar, but the declivity was a little greater. Therefore, both reached similar root length values with the highest saline concentrations. Thus, even though the cultivars presented similar responses, the Estanzuela cultivar provided a model with similar or greater 
Table 1. Correlation between amount of $\mathrm{NaCl}$, electrical conductivity and osmotic potential of the solution.

\begin{tabular}{lcc}
\hline $\mathrm{NaCl}(\mathrm{g} / \mathrm{L})$ & Electrical conductivity $\left(\mathrm{dSm}^{-1}\right.$ at $\left.25^{\circ} \mathrm{C}\right)$ & Osmotic potential $(\mathrm{MPa})^{*}$ \\
\hline 0.0 & 0.0 & 0.0 \\
2.9 & 5.6 & -0.2 \\
6.0 & 11.2 & -0.4 \\
8.9 & 16.7 & -0.6 \\
11.0 & 22.3 & -0.8 \\
\hline
\end{tabular}
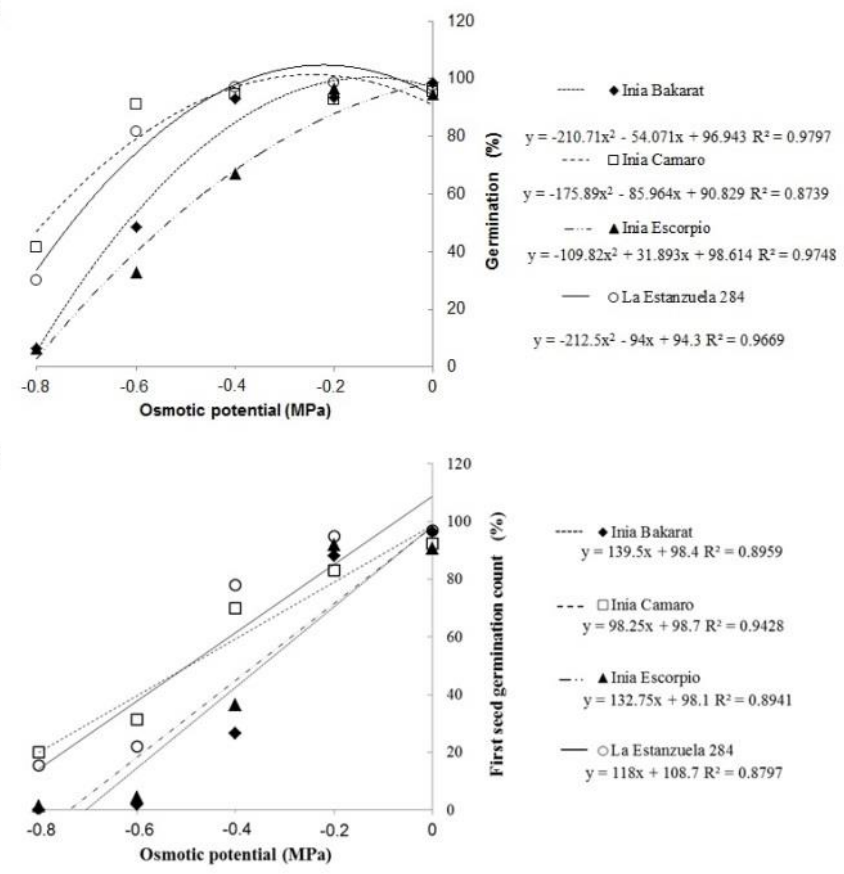

Fig 1. Regression of the germination test (A) and first ryegrass seed germination count (B) for ryegrass seeds from four cultivars with sodium chloride solutions of different osmotic potentials.
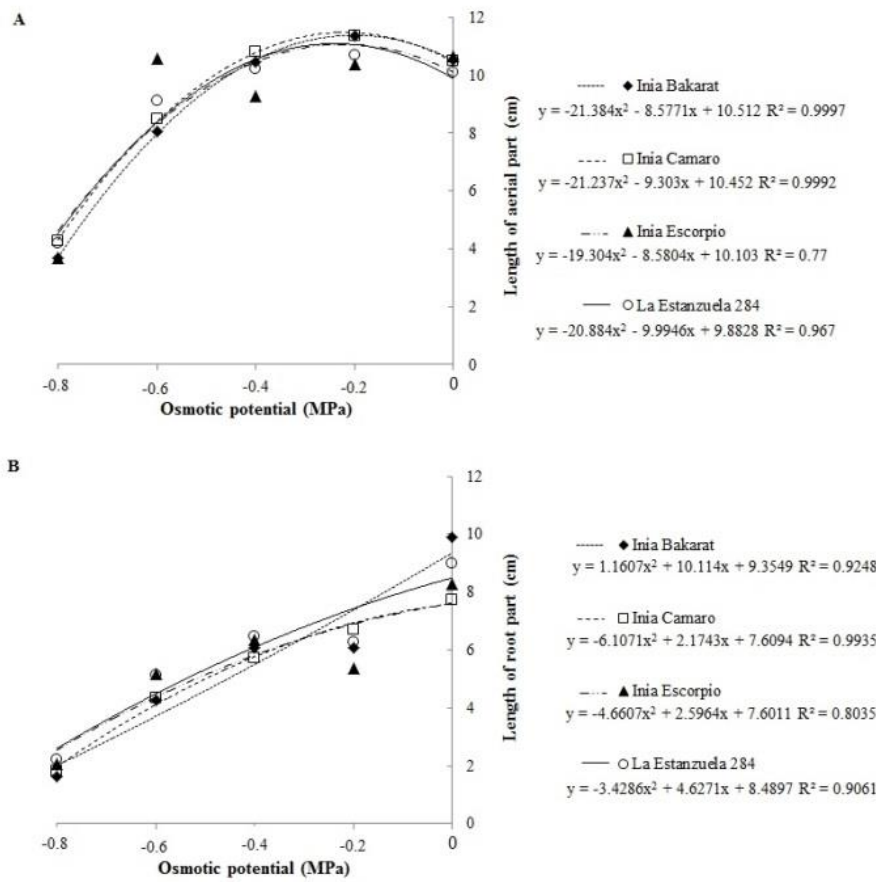

Fig 2. Regression between the length of the aerial part (A) and root length (B) of ryegrass seedlings from four cultivars with sodium chloride solutions of different osmotic potentials. 


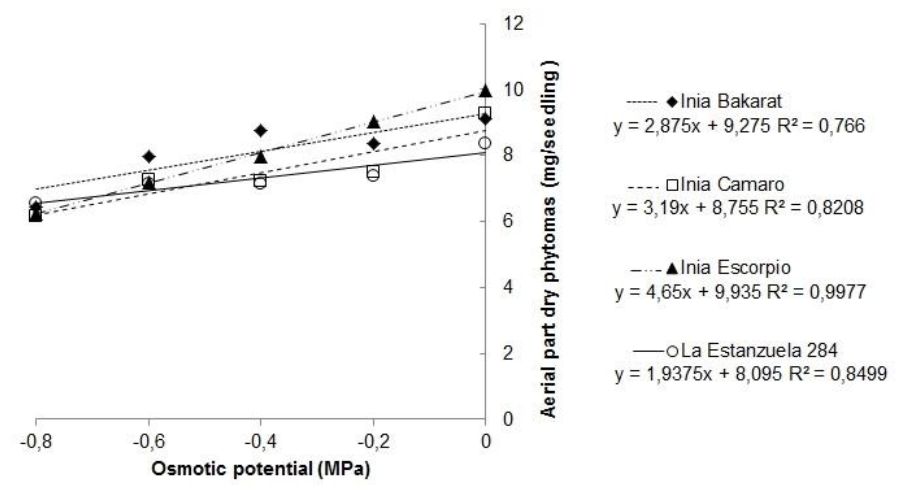

Fig 3. Regression between dry phytomass of the aerial part of ryegrass seedlings from four cultivars with sodium chloride solutions of different osmotic potentials.

root length values with increasing salinity levels, compared to other cultivars.

Similarly, Moterle et al. (2006) observed a reduction in root length as the osmotic potential of the solution was reduced, when worked with popcorn seeds.

According to Munns and Tester (2008), soil salinity influences plant growth, since high concentrations of salt in the soil make water extraction by roots difficult, as well as high salt concentrations are potentially toxic to plants.

The dry phytomass of the aerial part of the plant varied in relation to the osmotic potential (Fig. 3). The equations that best adjusted to the points were the $1^{\text {st }}$ degree ones. The cultivars presented greater plantlet dry mass with a zero dose than for the other doses. This result is reflected in the complementarity of the length of the aerial part, which followed the same tendency.

Growth inhibition caused by saline stress can be considered as a deviation of growth energy for maintenance, since ionic transport and distribution is regulated in various organs and within cells, such as through synthesis of organ solutes for osmoregulation, maintaining the integrity of cellular membranes. A reduction in dry mass can also reflect the metabolic cost of energy, associated with adaption to salinity and reductions in carbon gain (Richardson and McCree, 1985; Larré et al., 2014).

In a general analysis of the results, it was observed that the ryegrass seeds were sensitive to the salinity conditions imposed by the solutions with regards to osmotic potentials. A decrease in osmotic potential significantly altered the behavior of the ryegrass seedlings, causing a decline in seed vigor as well as in initial development, measured by the length of the aerial and root part of the seedlings.

\section{Materials and methods}

The study was conducted at the "Flávio Rocha" Didactic Seeds Analysis Laboratory of the Eliseu Maciel Agricultural Faculty at the Federal University of Pelotas.

\section{Plant material and treatment used}

Commercial seeds from four ryegrass cultivars were used: Inia Bakarat (diploid), Inia Scorpio (tetraploid), Inia Camaro (diploid), and La Estanzuela 284 (diploid). The origin of the seeds was PGG Wrightson Seeds Brazil.
The saline substrates contained sodium chloride $(\mathrm{NaCl})$ in five osmotic potentials $(0,-0.2,-0.4,-0.6$, and $-0.8 \mathrm{MPa})$, prepared according to the method of Richards (1954) as shown in Table 1.

\section{Evaluation of physiological seed quality}

In order to evaluate the physiological quality of the seeds subjected to different osmotic potentials, the following determinations were performed: germination, first germination test count, plantlet length and dry plantlet phytomass.

Germination: carried out in four samples, each with four subsamples of 50 seeds. Seeding was carried out in "gerbox" type acrylic boxes, on three sheets of blotting paper wetted with aqueous $\mathrm{NaCl}$ solutions with osmotic potentials of 0.0 , $0.2,-0.4,-0.6$, and $-0.8 \mathrm{MPa}$, in a proportion of two times the mass of the dry substrate. The "gerboxes" were kept in B.O.D. type germination chambers at $20{ }^{\circ} \mathrm{C}$ under constant white light for 14 days. Germination counts were carried out in accordance with the RAS (Brasil, 2009), calculating the average normal plantlet percentages.

First germination test count: carried out in conjunction with the germination test, counting at five days after sowing, according to the Rules for Testing Seeds (Brasil, 2009). The results were expressed as percentage of normal seedlings. Plantlet length: the substrate was prepared as described for the germination test with different saline concentrations, using four replicates of fifteen seeds each. Ten normal seedlings from each repetition, randomly obtained ten days after seeding, were measured using a graduated ruler, obtaining the lengths of the aerial part and the root system. The length of the aerial part was obtained by measuring the distance between the insertion of the basal portion of the primary root and the apex of the aerial part, while the length of the primary root was determined by measuring the distance between the apical and basal parts of the primary root. The results were expressed in $\mathrm{cm}$ as the average value per plantlet in each experimental unit (Nakagawa, 1999). Dry plantlet phytomass: after determining the length of the aerial part and the root system, the plant material was conditioned in dry paper bags and dried in a forced air circulation oven at a temperature of $60 \pm 2$ 으 for 72 hours. The samples were then placed to cool down in a desiccator containing silicon and subsequently weighed using $0.0001 \mathrm{~g}$ precision analytical scales (Nakagawa, 1999). 


\section{Experimental design and statistical analysis}

The trial was conducted using an entirely randomized design with a $4 \times 5$ (cultivar $\times$ osmotic potentials) factorial layout. When analysis of variance resulted in significance, polynomial regression analysis was carried out.

\section{Conclusion}

Saline stress affects the physiological quality of annual ryegrass seeds. Among the cultivars evaluated, the La Estanzuela 284 cultivar was the most tolerant to the action of saline stress. It is possible to calculate ryegrass in areas with salinity up to a mean value of $-0.2 \mathrm{MPa}$ osmotic potential. There was no significant decrease in seedling performance observed during the study.

\section{Acknowledgments}

We wish to thank the National Council of Scientific and Technological Development for granting a scholarship and PGG Wrightson Seeds Brazil for donating the seeds.

\section{References}

Amorin AV, Gomes Filho E, Bezerra MA, Prisco JT, Lacerda CF (2010) Respostas fisiológicas de plantas adultas de cajueiro anão precoce à salinidade. Rev Cienc Agronômica. 41(1):113-121.

Andreo-Souza $Y$, Pereira AL, Silva FD, Riebeiro-Reis RC, Evangelista, MRV, Castro RD, Dantas BF (2010) Efeito da salinidade na germinação de sementes e no crescimento inicial de mudas de pinhão-manso. Rev Bras Sementes. 32(2):83-92.

Bissani CA, Gianelo C, Camargo FAO, Tedesco MJ (2008) Fertilidade dos solos e manejo da adubação de culturas. 2ed. Porto Alegre: Editora Metrópole. 344.

Brasil (2009) Ministério da agricultura e da reforma agrária. Regras para análise de sementes. Brasília: SNDA/DNPV/CLAV. 395.

Carmona FC (2011) Salinidade da água e do solo e sua influência sobre o arroz irrigado. $132 \mathrm{f}$. Tese (Doutorado em Ciência do Solo) - Faculdade de Agronomia, Universidade Federal do Rio Grande do Sul, Porto Alegre.

Deuner C, Maia MS, Deuner S, Almeida AS, Meneghello GE (2011) Viabilidade e atividade antioxidante de sementes de genótipos de feijão-miúdo submetidos ao estresse salino. Rev Bras Sementes. 33(4):711-720.

Echer, FR, Custódio, CC, Hossomi, ST, Dominato, JC, Machado Neto, NB (2010) Estresse hídrico induzido por manitol em cultivares de algodão. Rev Cienc Agronômica. 41(4):638-645.

Harter LSH, Harter FS, Deuner C, Meneghello GE, Villela FA (2014) Salinidade e desempenho fisiológico de sementes e plântulas de mogango. Hort Brasileira. 32(1):80-85.

Klafke AV, Lopes RR, Franke LB (2012) Desempenho de sementes nuas e revestidas de azevém-anual em condições de estresse salino. Rev Bras Zootecnia. [online] 41(5):1093-1099.

Larcher W (2000) Ecofisiologia vegetal. São Carlos, Rima Artes e Textos. 531.

Larré CF, Marini P, Moraes CL, Amarante L, Moraes DM (2014) Influência do 24-epibrassinolídeo na tolerância ao estresse salino em plântulas de arroz. Semina Cienc Agrar. 35(1):67-76.

Lima BG, Torres SB (2009) Estresse hídrico e salino na germinação de sementes de Zizyphus joazeiro Mart (Rhammaceae). Rev Caatinga. 22:93-99.

Lima MG, Lopes NF, Moraes DM, Abreu CM (2005) Qualidade fisiológica de sementes de arroz submetidas a estresse salino. Rev Bras Sementes. 27(1):54-61.

Morais, FA de, Gurgel, MT, Oliveira, FHT de, Mota, AF (2011) Influência da irrigação com água salina na cultura do girassol. Rev Cienc Agronômica. 42(2):327-336.

Moterle LM, Lopes PC, Braccini AL, Scapim CA (2006) Germinação de sementes e crescimento de plântulas de cultivares de milho-pipoca submetidas ao estresse hídrico e salino. Rev Bras Sementes. 28(3):169-176.

Munns R, Tester M (2008) Mechanisms of salinity tolerance. Ann Rev Biology. 59:651-681.

Nakagawa J (1999) Testes de vigor baseados no desempenho das plântulas. In.: Krzyzanowski FC, Vieira RD, França Neto JB (eds). Vigor de sementes: conceitos e testes. Londrina: ABRATES. 2.1-2.24.

Nizam I (2011) Effects of salinity stress on water uptake, germination and early seedling growth of perennial ryegrass. Afr J Biotechnol. 10(51):10418-10424.

Richards LA (1954) Diagnosis and improvement of saline and alkali soils. Washington: USDA, 100.

Richardson SG, McCree KJ (1985) Carbon balance and water relations of sorghum exposed to salt and water stress. Plant Physiology. 79(11):1015-1020.

Terra-Lopes ML, Carvalho PCF, Anghinoni I, Santos DT, Aguinaga AAQ, Flores JPC, Moraes A (2009) Sistema de integração lavoura-pecuária: efeito do manejo da altura em pastagem de aveia preta e azevém anual sobre o rendimento da cultura da soja. Cienc Rural. 39(5):14991506.

Torres SB (2007) Germinação e desenvolvimento de plântulas de melancia em função da salinidade. Rev Bras Sementes. 29(3):77-82. 